\title{
PEMIKIRAN SYAIKH NAWAWI AL-BANTANI TENTANG ILMU DAN ULAMA DALAM KITAB QAMI'UT TUGHYAN
}

\author{
Ismail \\ Institut Agama Islam Al-Khairat Pamekasan, Email: yajlisismail@gmail.com \\ Moh. Wardi \\ Institut Dirosat Islamiyah Al-Amien Prenduan Sumenep \\ Email: mohwardi84@gmail.com
}

\begin{abstract}
Abstrak:
Keberhasilan Syaikh Nawawi menyusun kitab syarah ini menunjukkan bahwa kemasyhuran Syaikh Nawawi sebagai ahli syarah kitab tidak terbantahkan, karena selain dari kitab qami'ut tughyan ini, banyak sekali kitab syarah lainya yang dihasilkan oleh Syaikh Nawawi. Pokok pikiran Syaikh Nawawi tentang ilmu dan ulma dalam kitab qami'ut tughyan ini antara lain: (a) pembahasan tentang landasan nas hadis tentang ilmu yang dapat memotivasi umat Islam untuk mencari ilmu sedemikian rupa; (b) pembahasan tentang niat pencari ilmu yang dibenarkan menurut syariat; (c) pembahasan tentang kewajiban menyebarkan ilmu terletak pada setiap orang yang menguasai suatu bidang ilmu; dan (d) pembentukan karakter pendidik yang komitmen terhadap ilmunya, konsisten dalam mendidik, dan mengutamakan tujuan akhirat, sehingga dengan karakter ini, seorang pendidik akan melaksanakan pendidikan dengan baik dan menghasilkan generasi yang baik untuk kepentingan dunia dan akhirat.
\end{abstract}

Kata kunci: Syaikh Nawawi al-bantani, Ilmu, ulama, qami’ut tughyan

\begin{abstract}
:
The success of Shaykh Nawawi compiling this book shows that the fame of Shaykh Nawawi as an expert in the book sharah is indisputable, because apart from this book of qami'ut tughyan, there are many other syarah books produced by Shaykh Nawawi. The main thoughts of Shaykh Nawawi about science and ulma in the book qami'ut tughyan include: (a) discussion of the foundation of the hadith scriptures on science that can motivate Muslims to seek knowledge in such a way; (b) discussion of the intention of knowledge seekers justified according to the Shari'a; (c) discussion of the obligation to spread knowledge lies in every person who controls a field of science; and (d) the formation of the character of educators who are committed to their knowledge, consistent in educating, and prioritizing the purpose of the hereafter, so that with this character, an educator will carry out education well and produce a good generation for the interests of the world and the hereafter.
\end{abstract}

Keywords: Shaykh Nawawi al-Bantani, Science, ulama, qami'ut tughyan 


\section{Pendahuluan}

Syaikh Nawawi al-bantani merupakan salah satu generasi muslim Indonesia yang masyhur sebagai ulama dengan kapasitas keilmuan yang mumpuni. Hal ini terlihat dari berbagai karyanya, dari syarah kitab-kitab klasik ${ }^{1}$ hingga tafsir marah labid. ${ }^{2}$ Namun, Syaikh Nawawi bukan satu-satunya ulama Indonesia yang mendaptkan pengakuan karena karyanya serta kiprah dalam pengembangan ilmu keislaman di Timur Tengah, karena sebelum masa Syaikh Nawawi al-Bantani, telah banyak dikenal ulama Indonesia yang serupa atau bahkan lebih dari Syaikh Nawawi. Kemasyhuran ulama Indonesia sebelum Syaikh Nawawi disebut oleh Azyumardi Azra bukan hanya pada kapasitas intelektual mereka, bahkan dalam membentuk jaringan ulama se-daerah Indonesia. Azra menyebutnya dengan jaringan ulama Timur Tengan dan kepulauan nusantara abad XVII-XVII. ${ }^{3}$ Hasil penelitian Azra menunjukkan bahwa pada abad ke-17-18 terdapat komunitas yang disebut dengan ashab al-jawiyyin, yakni mereka yang balajar di haramayn yang berasal dari kepulauan nusantara. ${ }^{4}$ Kemudian mereka banyak melakukan pembaharuan, membentuk pemikiran dan praktik keagamaan kaum muslim Indonesia. Di antaranya Nur al-Din al-Raniri, ${ }^{5}$ Abd al-Rauf al-Sinkili,, ${ }^{6}$ Muhammad Yusuf alMaqassari, ${ }^{7}$ al-Palimbani, ${ }^{8}$ al-Banjari, ${ }^{9}$ dan al-Patani. ${ }^{10}$ Penelitian Azra hanya pada abad ke-17-18, sementara Syaikh Nawawi hidup di abad ke-19. Artinya Syaikh Nawawi merupakan penerus generasi sebelumnya dalam mengokohkan keulamaan muslim Indonesia di kancah internasional.

Sementara itu, kajain tentang individu Syaikh Nawawi telah banyak dilakukan oleh peneliti, antara lain: Pemikiran Syekh Nawawi al-Bantani Dalam Bidang Hukum Islam (Tentang Taklif dan Mukalaf) oleh Khusaeri11, Syeikh Nawawi al-Bantani alJawi Ilmuan Spesialis Ahli Syarah Kitab Kuning oleh Ali Muqoddass2, Inklusifitas Pemikiran Syaikh Nawawi al-Bantani; Studi Atas Konsep Ahl al-Fatrah dalam Tafsir Marāh Labīd oleh Rofik Maftuh', Pemikiran Pendidikan Syekh Nawawi Al-Bantani

\footnotetext{
${ }^{1}$ Khusaeri, "Pemikiran Syekh Nawawi al-Bantani Dalam Bidang Hukum Islam (Tentang Taklif dan Mukalaf)”, Al-A'raf: Jurnal Pemikiran Islam dan Filsafat, Vol. XI, No. 1, Januari-Juni 2014, 18-20.

${ }^{2}$ Ali Muqoddas, "Syeikh Nawawi Al-Bantani Al-Jawi: Ilmuan spesialis ahli syarah kitab kuning”. Jurnal Tarbawi. Vol. 11. No. 1. Januari-Juni 2014

3 Azyumardi Azra, Jaringan Ulama Timur Tengah dan Kepulauan Nusantara Abad XVII-XVIII: Akar Pembaruan Islam Indonesia (Jakarta: Kencana Prenada Media Group, 2013).

4 Ibid., xxvi.

5 Ibid., 205-237.

6 Ibid., 238-269.

7 Ibid., 270-310.

8 Ibid., 316-326.

9 Ibid., 327-336.

10 Ibid., 337-347.

11 Khusaeri, "Pemikiran Syekh Nawawi al-Bantani Dalam Bidang Hukum Islam (Tentang Taklif dan Mukalaf)", Al-A'raf: Jurnal Pemikiran Islam dan Filsafat, Vol. XI, No. 1, Januari-Juni 2014.

12 Ali Muqoddas, "Syeikh Nawawi Al-Bantani Al-Jawi Ilmuan Spesialis Ahli Syarah Kitab Kuning", Jurnal Tarbawi, Vol. 11. No. 1. Januari-Juni 2014.

${ }^{13}$ Rofik Maftuh, "Inklusisifitas Pemikiran Syaikh Nawawi al-Bantani; Studi Atas Konsep Ahl al-Fatrah dalam Tafsir Marāh Labīd”, MAGHZA: Jurnal Ilmu Al-Qur'an dan Tafsir, Vol. 3, No. 1, Januari-Juni 2018.
} 
oleh Bashori14, Tafsir Nusantara, Studi Kritis Terhadap Marāḥ Labīd Nawawi alBantani oleh Anshar Bahary ${ }^{15}$, Konsep Tasawuf Syaikh Nawawi al-Bantani oleh M. Ridwan Hidayatullah dan Aceng Kosasih Fahrudin ${ }^{16}$ dan beberapa karya lainnya. Dari beberapa karya tersebut, kajian yang fokus tentang pemikiran Syaikh Nawawi dalam bidang pendidikan adalah hasil kajian Bashori dengan judul pemikiran pendidikan syekh Nawawi al-Bantani. Oleh karena itu, kajian dalam atikel ini merupakan materi yang belum dikaji sebelumnya.

\section{Pembahasan}

\section{Selayang Pandang tentang Syaikh Nawawi dan Kitab Qami'ut Tughyan}

Syaikh Nawawi memiliki nama lengkap Muhammad Nawawi bin Umar bin Arbi, lahir di Banten pada tahun 1813 M/1230 H, dan wafat di Ma'la Mekkah Saudi Arabia pada tahun 1897 M/1314 H. Karena tempat kelahirannya ini kemudian beliau masyhur disebut Syaikh Nawawi al-Bantani. ${ }^{17}$ Selain dikenal sebagai penulis dan pensyarah kitab,18 Syaikh Nawawi juga dianggap sebagai mahaguru bagi kalangan ulama Indonesia. Syaikh Nawawi telah banyak berjasa meletakkan landasan pengembangan pendidikan Islam, pesantren utamanya dengan melahirkan tokoh intelektual pesantren. Semisal Syaikh Kholil Bangkalan, Madura, KH. Hasyim Asy'ari Jombang, KH. Asy'ari Bawean, KH. Tubagus Muhammad Asnawi Pandeglang Banten, KH. Tubagus Bakri Sempur-Purwakarta, KH. Abdul Karim Banten. ${ }^{19}$

Kitab qami'ut tughyan merupakan kitab syarah karya Syaikh Nawawi. Kitab ini mensyarahi nadham/syi'ir karya Syaikh Zainuddin bin 'Ali bin Ahmad. Syi'ir ini merupakan bagian dari kitab syu'b al-iman karya Syaikh Zainuddin itu. Kitab syu'b al-iman, merupakan hasil translitrasi ke bahasa Arab dari kitab syu'b al-iman yang berbahasa Persi karya dari Syaikh Nuruddin al-ijiy. Syi'ir syu'b al-iman karya Syaikh Zainuddin ini sebanyak 26 bait, kemudian Syaikh Nawawi menambahkan 3 bait di awal, dan Abdul Mun'im menambahkan 1 bait di akhir, sehingga jumlahnya menjadi 30 bait. Syaikh Nawawi dikenal sebagai ilmuan spesialis ahli syarah kitab kuning. Karena kitab syarah karya Syaikh Nawawi bukan hanya qami'ut tughyan saja, melainkan banyak sekali kitab-kitab yang lain. ${ }^{20}$

\footnotetext{
${ }^{14}$ Bashori, “Pemikiran Pendidikan Syekh Nawawi Al-Bantani”, Hikmah: Jurnal Pendidikan Islam, Vol. 6, No. 1 Januari-Juni 2017.

${ }^{15}$ Anshar Bahary, "Tafsir Nusantara, Studi Kritis Terhadap Marāh Labīd Nawawi al-Bantani", Jurnal Ulul Albab, Volume 16 No. 2 tahun 2015.

16 M. Ridwan Hidayatullah dan Aceng Kosasih Fahrudin, "Konsep Tasawuf Syaikh Nawawi alBantani", Jurnal Tarbawi, Vol 2 tahun 2015.

17 Muhammad Ulul Fahmi, Ulama Besar Indonesia Biografi dan Karyanya (Kendal: Amanah Grafika, 2008), 4.

18 Ali Muqoddas, "Syeikh Nawawi Al-Bantani Al-Jawi: Ilmuan spesialis ahli syarah kitab kuning". Jurnal Tarbawi. Vol. 11. No. 1. Januari-Juni 2014, 7.

${ }^{19}$ Muhammad Ulul Fahmi, Ulama Besar Indonesia Biografi dan karyanya ..., 9-10.

${ }^{20}$ Ali Muqoddas, "Syeikh Nawawi Al-Bantani Al-Jawi: Ilmuan spesialis ahli syarah kitab kuning". Jurnal Tarbawi. Vol. 11. No. 1. Januari-Juni 2014
} 
Kitab qami'ut tughyan yang penulis gunakan dalam menganalisis pemikiran Syaikh Nawawi tentang ilmu dan ulama ini adalah cetakan yang diterbitkan oleh penerbit al-haramayn Sanggapura Indonesia, tanpa tertulis tahun penerbitan.

\section{Landasan Motivasi Mencari Ilmu}

Syaikh Nawawi mengutip beberapa hadis Nabi Muhammad Saw, tentang talab al-ilmi. Di antara hadis tersebut adalah:

“dari Abdullah bin Mas'ud, dia berkata. Rasulullah Saw bersabda “barang siapa mempelajari satu bab dari ilmu, kemudian dia mengambil manfaat dengan ilmu itu di dalam akhirat dan dunianya, maka hal itu lebih baik dari hidup di dunia selama 7000 tahun dengan puasa penuh di siang harinya, dan bangun di malam harinya sebagai ibadah yang diterima bukan di tolak". ${ }^{21}$

Merujuk pada hadis di atas, Syaikh Nawawi memberikan motivasi yang sangat besar kepada kaum muslim untuk mencari dan menekuni bidang ilmu tertentu. Syaikh Nawawi menunjukkan bahwa seorang pencari ilmu dapat meperoleh kebaikan yang sangat besar. Kebaikan itu diperoleh oleh seorang pencari ilmu yang berhasil mendapatkan ilmu yang bermanfaat bagi diriya untuk kehidupan dunia serta akhiratnya. Dengan hadis itu pula, Syaikh Nawawi menunjukkan bahwa pencari ilmu yang sukses akan mendapatkan yang lebih baik dari hidup di dunia selama 7000 tahun dengan selalu berpuasa di siangnya, dan selalu bangun untuk shalat malam. Betapa besar kebaikan yang dijanjikan oleh Allah Swt bagi pencari ilmu. Dengan hadis ini pula, Syaikh Nawawi berharap agar para kaum muslim terus terdorong untuk menjadi pencari ilmu, untuk suka mencari ilmu, untuk mengutamakan mencari ilmu dari pada kepentingan dunia yang lain. Hadis ini merupakan sabda Nabi Muhammad Saw, yang diyakini oleh seluruh umat Islam, bahwa apa yang dikandung oleh hadis adalah kebenaran.

Hadis yang lain yang dirujuk oleh Syaikh Nawawi adalah:

“dari Mu’adz bin Jabal, dia berkata. Rasulullah Saw bersabda “belajarlah kalian tentang suatu ilmu, karena sesungguhnya mempelajarinya adalah kebaikan, membacanya adalah tasbih, membahasnya adalah jihad, mencarinya adalah ibadah, mengajarkannya adalah shadaqah, memberikannya kepada yang berhak adalah taqarrub. Berfikir tentang suatu ilmu menggantikan puasa. Mengulang pelajaran menggantikan bangun di malam hari". ${ }^{22}$

Kemudian dengan hadis yang diriwayatkan oleh Mu'adz bin Jabal, Syaikh Nawawi menjelaskan bahwa berdasarkan sabda Nabi Muhammad Saw, praktik mencari ilmu sebanding dengan beberapa amalan yang bernilai pahala tinggi menurut Allah Swt, yaitu: mempelajari suatu ilmu (berusaha untuk memahaminya) bernilai kebaikan (hasanah). Membaca suatu bidang ilmu sebanding dengan tasbih, yakni membaca kalimat subhana Allah. Membahas suatu bidang ilmu sebanding dengan jihad. Praktik mencari ilmu sebanding dengan melaksanakan suatu ibadah

${ }^{21}$ Syaikh Muhammad Nawawi bin Umar, Qami'ut Tughyan ala Manzumat Shu'b al-Iman (Sanggapura, Indonesia: al-Haramyn, tt), 7.

${ }^{22}$ Syaikh Muhammad Nawawi bin Umar, Qami'ut Tughyan ala Manzumat Shu'b al-Iman..., 7. 
yang diterima oleh Allah Swt. Mengajarkan suatu ilmu kepada orang lain sebanding dengan memberikan sadaqah. Menyebarkan ilmu kepada banyak orang bernilai taqarrub ilallah. Berkontemplasi tentang sebuah ilmu sebanding dengan ibadah puasa, dan mengulang pelajaran yang bisa dilakukan setiap siang atau malam hari adalah sebanding dengan bangun di tengah malam untuk melaksanakan shalat tahajjud. Itulah beberapa perbandingan nilai kebaikan yang terdapat dalam praktik mencari ilmu. Betapa besar motivasi yang diberikan oleh Syaikh Nawawi untuk mendorong kaum muslimin mencintai ilmu, menguasai ilmu, menyebarluaskan ilmu, demi kebaikan kehidupan dunia dan akhiran dirinya maupun orang lain.

"Rasulullah bersabda: carilah ilmu, meskipun terdapat lautan api di antaramu dan ilmu". ${ }^{23}$

Hadis di atas memberikan pemahaman kepada kita bahwa Syaikh Nawawi menunjukkan bahwa begitu pentingnya mencari ilmu sehingga tidaklah dapat dihalangi oleh apapun. Bahkan, mencari ilmu harus tetap dilaksankan meskpiun harus melewati lautan api. Tidak ada alasan yang dibenarkan untuk tidak mencari ilmu. Karena mencari ilmu adalah perintah, mencari ilmu adalah kebutuhan, mencari ilmu adalah kebaikan. Oleh karena itu, menurut Syaikh Nawawi, tidak ada penghalang yang dapat mengubah pentingnya mencari ilmu.

"Rasulullah bersabda, carilah ilmu sejak lepas dari buaian ibu hingga memasuki liang kubur". 24

Sedangkan hadis di atas menunjukkan bahwa Syaikh Nawawi menjelaskan kepada kaum muslimin, bahwa sesungguhnya masa mencari ilmu, di dalam Islam, adalah sepanjang hayat. Mencari ilmu harus dilaksanakan selama hidup, selama bernafas. Hadis tersebut menjelaskan bahwa Nabi Muhammad Saw, memerintahkan umatnya untuk mencari ilmu sejak lepas dari gendogan ibu hingga maut menjemput, hingga mati, hingga masuk ke dalam kubur. Hal ini menunjukkan bahwa betapa urgennya mencari ilmu bagi kaum muslim. Dengan hadis itu, diharapkan kaum muslim dapat terdorong untuk tekun mencari ilmu.

\section{Niat Mencari Ilmu}

Syaikh Nawawi berpandangan bahwa mencari ilmu merupakan ibadah dan sebagaimana ibadah-ibadah yang lain di dalam Islam yang mempersyaratkan adanya niat agar ibadah yang dilakukan sesuai dengan syariat. Serta pula, segala amal perbuatan manusia dinilai oleh Allah Swt menurut niatan yang mendasarinya. Sebagaimana hadis Nabi yang berbunyi "sesungguhnya segala perbuatan dengan niat". 25

Maka dalam konteks ini, Syaikh Nawawi menentukan bahwa pencari ilmu wajib hukumnya untuk menentukan niatnya. Syaikh Nawawi mengatakan:

\footnotetext{
${ }^{23}$ Ibid.

24 Ibid.

${ }^{25}$ Abi Abdillah Muhammad bin Ismail al-Bukhari, Matn al-Bukhari Juz I (Sanggapura, Indonesia: AlHaramayn, $\mathrm{tt}), 6$.
} 
"Wajib hukumnya bagi pencari ilmu untuk berniat dalam upayanya mencari ilmu demi memperoleh ridla Allah Swt dan tempat di akhirat, menghilangkan kebodohan dari dirinya dan dari orang lain, menghidupkan agama, mengekalkan Islam dengan ilmu. Serta pencari ilmu hendaknya berniat untuk bersyukur kepada Allah Swt atas nikmat akal dan kesehatan yang telah diberikan. Pencari ilmu tidak berniat untuk menarik perhatian manusia dengan ilmunya, untuk mendapatkan materi duniawi, untuk dimulyakan penguasa, dan lain-lainya". ${ }^{26}$

Melalui pernyataan dan penjelasan tentang niat mencari ilmu, dapat dipahami bahwa Syaikh Nawawi menekankan pentingnya niat mencari ilmu hanya karena Allah Swt. Sama dengan ibadah-ibadah yang lain, niat melakukannya hanya karena Allah Swt. Syaikh Nawawi menegaskan pula bahwa terdapat 6 (enam) hal sebagai niat dalam mencari ilmu, yaitu: (1) memperoleh ridla Allah Swt; (2) memperoleh tempat surga di Akhirat; (3) menghilangkan kebodohan, baik dari diri sendiri maupun dari orang lain; (4) menghidupkan agama Islam; (5) mengekalkan Islam di muka bumi; (6) mensyukuri nikmat yang diberikan oleh Allah Swt terutama nikmat akal dan kesehatan fisik dan psikis. Tentunya dari keenam niat yang harus tertanam di dalam hati para pencari ilmu adalah yang pertama, yakni mengharap ridla Allah Swt. Karena apapun yang diperoleh dari pencarian ilmu, tanpa adanya ridla Allah Swt, tidaklah ada artinya. Meskipun ilmu yang diperoleh dari proses belajar tidak melimpah, namun karena niatannya hanyalah mengharap ridla Allah Swt, maka ilmu itu akan bermanfaat, ilmu itu akan menjadi jalan untuk meraih hidayah Allah Swt. Sebagaimana hadis Nabi Saw: barang siapa yang bertambah ilmunya, namun tidak bertambah hidayahnya, maka yang bertambah pada orang itu adalah semakin jauh dari Allah Swt. Di sinilah pentingnya apa yang disampaikan oleh Syaikh Nawawi mengenai niatan memperoleh ridla Allah Swt dari proses pencarian ilmu, dan hendaknya para peserta didik dapat mempertahankan niatanniatan tersebut sebagaimana dijelaskan oleh Syaikh Nawawi.

Kemudian juga, Syaikh Nawawi menunjukkan beberapa niat yang tidak diperkenankan bagi seorang pencari ilmu, pertama berniat agar orang-orang datang menghadap kepadanya karena ilmunya. Karena jika demikian, maka seorang pencari ilmu pada akhirnya akan menjadi sombong di hadapan orang lain, dan dikhawatirkan pula akan menjadi sombong di hadapan Allah Swt. Kedua berniat untuk mendapatkan keuntungan materi duniawi. Karena niat semacam ini akan membawa si pencari ilmu pada materialisme, dan melupakan akhirat, serta akan melupakan kewajibannya sebagai hamba Allah Swt yang wajib beribadah dan menyembah hanya kepada-Nya. Ketiga berniat mencari kemulyaan dari penguasa. Sama dengan niat yang kedua, niat ketiga ini sangatlah dilarang di dalam Islam, karena niat semacam ini sangatlah duniawi dan melupakan akhirat. Sementara perspektif Islam, ilmu yang bermanfaat adalah ilmu yang memberikan pengaruh positif terhadap pemiliknya di dalam kehidupan dunia dan akhirat sekaligus. Oleh

\footnotetext{
${ }^{26}$ Syaikh Muhammad Nawawi bin Umar, Qami'ut Tughyan ala Manzumat Shu'b al-Iman ..., 7.
} 
karena itu, Syaikh Nawawi mengatakan bahwa pencari ilmu tidak berniat dalam mencari ilmu untuk beberapa hal yang disebutkan.

\section{Ilmu Kasbiy dan Ilmu Sima'iy}

Selanjutnya, Syaikh Nawawi menjelaskan tentang klasifikasi ilmu menurut cara memperolehnya. Syaikh Nawawi mengatakan bahwa:

"Sesungguhnya memperoleh ilmu dilakukan dengan dua cara; kasbiy dan sima'iy. Memperoleh ilmu dengan kasbiy berarti memepalajari ilmu dengan terus menerus membaca literatus dengan arahan dari ustadz (pendidik). Sedangkan meperoleh oleh dengan sima'iy berarti belajar dari ulama dengan cara mendengarkan berbagai hal yang berhubungan dengan masalah agama maupun dunia".

Jadi, menurut Syaikh Nawawi, dilihat dari cara meperoleh suatu ilmu pengetahuan serta penggunaan literatur dan ustadz, maka memperoleh ilmu diklasifisikan menjadi dua jenis. Pertama ilmu kasbiy. Ilmu kasbiy merupakan ilmu yang diperoleh oleh pencari ilmu melalui proses membaca literatur, atau referensireferensi terkait, serta mendapatkan bimbingan dari seorang pendidik atau lebih. Dalam hal ini, difahami bahwa jenis pertama ini merupakan proses belajar yang memungkinkan bagi pencari ilmu untuk secara teratur mempelajari atau mengkaji literatur-literaur tertentu yang relevan dengan ilmu yang dipelajarinya. Demikian juga pada jenis ini keberadaan ustadz atau pendidik adalah mutlak. Karena dalam proses ini, pencari ilmu mendapat arahan dan bimbingan dari pendidik agar tidak terjadi kesalahan di dalam memahami atau mencerna isi literatur yang dikaji. Pada posisi ini, pencari ilmu merupakan orang yang masih sangat memungkinkan untuk menggali ilmu dari literatur dan bimbingan pendidik. Kemungkinan itu dapat dikarenakan waktu yang cukup, biaya, dan kesempatan. Karena pada umumnya proses yang seperti terjadi pada praktik pendidikan formal, non formal, maupun informal.

Proses pertama ini pula terlihat bahwa pencari ilmu diberi kesempatan untuk memilih bidang ilmu yang dikehendaki. Karena dalam proses ini, pendidik yang akan mendampinginya juga harus memiliki kompetensi keilmuan yang relevan. Semisal, jika menghendaki belajar tentang hadis, maka dia harus mengkaji kitabkitab ulum al-hadis serta mendapatkan bimbingan dari ahli hadis. Demikian juga pada bidang ilmu yang lainnya.

Kedua ilmu sima'iy. Menurut Syaikh Nawawi, ilmu sima'iy merupakan ilmu yang diperoleh hanya dari mendengarkan penyampaian-penyampaian dari seorang ulama atau lebih, yang berkaitan dengan agama maupun dunia. Dalam proses belajar ini, pencari ilmu tidak diminta untuk membaca atau mengkaji literatur tertentu. Karena pencari ilmu langsung mendapatkan penjelasan dari seorang alim. Proses ini memberikan kemudahan kepada para pencari ilmu, karena dia hanya diminta untuk datang saja kepada ulama. Namun, model ini membatasi pencari ilmu dalam mempelajari berbagai bidang ilmu. Karena bidang ilmu atau kajiannya pun ditentukan oleh ulama pendidiknya. Model ini terjadi secara informal saja. 
Dalam rangka efektifitas jenis ilmu sima'iy, Syeikh Nawawi menjelaskan beberapa prinsip yang harus dipegang oleh pencari ilmu model ini. Dia mengatakan:

"Hal ini (sima'iy) hanya dapat diperoleh dengan mencintai ulama, bergaul dengan ulama, duduk bersama ulama, dan mendatangkan ulama". ${ }^{27}$

Menurut Syeikh Nawawi, ilmu sima'iy dapat diperoleh dengan beberapa syarat, antara lain: (1) mencintai ulama; (2) bergaul dengan ulama; (3) duduk bersama ulama; dan (4) mendatangkan ulama. Keempat cara tersebut akan mendorong ulama untuk meberikan nasihat dan tausiyah kepada umat. Dengan nasihat dan tausiyah itulah ilmu sima'iy diperoleh. Syeikh Nawawi juga menunjukkan bahwa jika umat tidak mencintai ulama, tidak suka bergaul degan ulama, tida mau duduk bersama ulama, dan tidak mau mendatangkan atau mendatangi ulama, maka kaum awam tidak akan pernah mendapatkan tambahan ilmu, dan karena itu pula, maka kaum awam akan semakin terejerumus ke dalam kebodohan. Syaikh Nawawi juga menerangkan dalam hal ini, bahwa mencintai ulama merupakan cara utama bagi umat untuk mendapatkan siraman ilmu dari para ulama. Tanpa rasa cinta terhadap ulama, maka jauhlah seseorang dari nur ilmu. Sedangkan al-Ghazali membedakan ilmu menurut cara meperolehnya menjadi dua jenis, yaitu jenis al-tallum al-insaniy dan al-ta'allum al-rabbaniy. ${ }^{28}$

\section{Kewajiban Menyebarkan Ilmu}

Selanjutnya, Syaikh Nawawi menjelaskan tentang beberapa hal yang terkait dengan penyebaran ilmu di antara suatu kaum. Syaikh Nawawi mengatakan:

"penyebaran ilmu di dalam Islam berdasarkan pada Sabda Rasulullah Saw:

"hendaklah yang hadir di antaramu menyampaikan kepada yang tidak hadir".

Yakni wajib hukumnya atas orang yang mendengarkan di antaramu apa yang saya katakan untuk menyampaikannya kepada orang yang tidak mendengarkannya. Hadis ini adalah khitab terhadap para sahabat Nabi, kemudian terhdap orang-orang setelah mereka hingga hari kiamat". ${ }^{29}$

Menurut Syaikh Nawawi, menyebarkan ilmu adalah wajib. Sebagaimana sabda Nabi Saw di atas. Secara praktis, kewajiban penyebaran ilmu ada pada setiap orang yang telah menguasai ilmu itu. Sebagaimana Nabi Saw, mengingatkan agar yang hadir pada majlis Nabi, hendaknya meneruskan apa yang diketahuinya kepada para sahabat yang lain, yang tidak hadir ketika majlis itu dilaksanakan. Tentunya, yang hadir pada majlis itu merupakan para sahabat yang telah menguasai ilmu tertentu yang telah disampaikan oleh Nabi. Kemudian, praktik penyebaran ilmu yang dicontohkan Nabi kepada para sahabat, menurut Syaikh Nawawi, berlaku juga untuk umat Islam setelahnya. Jadi umat Islam di setiap masa hendaknya menyebarkan ilmunya kepada umat Islam yang belum mengetahuinya. Praktik ini harus terus dijaga hingga hari kiamat. Selama kehidupan masih ada maka penyebaran ilmu harus tetap dilaksanakan oleh umat Islam.

\footnotetext{
${ }^{27}$ Syaikh Muhammad Nawawi bin Umar, Qami'ut Tughyan ala Manzumat Shu'b al-Iman ..., 7.

${ }^{28}$ Al-Ghazali, al-Risalah al-Ladduniyah (Mesir: Kurdistan al-Ilmiyah, 1328), 23.

${ }^{29}$ Syaikh Muhammad Nawawi bin Umar, Qami'ut Tughyan ala Manzumat Shu'b al-Iman ...,8.
} 
Dalam konteks ini, Syaikh Nawawi menunjukkan bahwa ilmu merupakan sesuatu yang urgen di dalam Islam. Urgensi ilmu menurutnya, bukan hanya pada penguasaan saja, melainkan juga pada penyebarannya. Posisi penyebaran ilmu tidak jauh berbeda dengan penguasaan ilmu, karena setelah kewajiban penguasaan ilmu ditunaikan, maka kewajiban berikutnya adalah menyebarluaskan ilmu yang dikuasai kepada seluruh umat manusia. Penyebaran ilmu dapat dilakukan dengan berbagai media yang tersedia, baik media lisan, media tulisan, media gambar, maupun yang lainnya.

Syaikh Nawawi mengatakan bahwa:

"maka wajib hukumnya ahl al-ilmi (pemilik ilmu) bertabligh (menyampaikan ilmu yang dimilikinya). Setiap orang yang telah mempelajari suatu masalah, maka berarti dia merupakan ahl al-ilmi (pemilik ilmu). Setiap orang awam yang telah mengetahui syarat-syarat shalat, maka dia wajib mengajarkan kepada orang awam lainnya. Jika tidak, maka berarti dia ikut serta dalam perbuatan dosa". 30

Pendapat Syaikh Nawawi ini menjelaskan kepada kita bahwa menurut Syaikh Nawawi, menyebarkan ilmu atau tabligh merupakan kewajiban individual, yang berarti bahwa kewajiban ini berlaku kepada setiap orang yang telah memiliki suatu ilmu untuk menyampaikan kepada orang lain. Setiap orang yang telah mempelajari suatu masalah, maka berarti dia telah menguasai ilmu tentang masalah tersebut. Hal ini disebut dengan ahl al-ilmi. Dan apa bila seseorang telah berstatus ahl al-ilmi, maka dia berkewajiban untuk menyebarkan ilmu kepada yang lainnya.

Dalam pernyataan di atas, Syaikh Nawawi juga memberikan contoh praktis mengenai penyebaran ilmu. Menurutnya, setiap orang awam yang telah mempelajari beberapa syarat shalat, maka diwajibkan kepadanya untuk mengajarkan syarat-syarat shalat tersebut kepada orang awan lainnya. Contoh ini jelas sekali untuk orang awam. Tapi contoh ini juga merupakan analogi, bahwa orang awam saja, yang hanya mengetahui syarat-syarat shalat diwajibkan untuk menyebarkan ilmunya, apa lagi mereka yang menguasai banyak ilmu, mereka yang telah mengkaji berbagai macam kitab maupun buku, mereka yang telah mengerti berbagai macam teori, tentunya, meskipun tidak bisa dikatakan lebih wajib, tetapi akan lebih etis untuk menunaikan kewajiban itu.

Terkait dengan pemetaan wilayah dalam pelaksanaan kewajiban penyebaran ilmu, Syaikh Nawawi mengatakan bahwa:

"Keberadaan seorang faqih yang mengajar orang-orang dan memberikan pemahaman kepada mereka di setiap masjid atau daerah di suatu wilayah adalah wajib. Begitu juga, di suatu desa. Dan wajib kifayah pula bagi setiap faqih, yang telah menunaikan kewajiban individualnya, untuk keluar ke tetangga wilayahnya untuk mengajarkan agama kepada mereka, mengajarkan beberapa fardlu yang disyariatkan, dan faqih yang melaksanakan itu diharuskan membawa bekal makanan sendiri, dan tidak memakan makanan

\footnotetext{
${ }^{30}$ Syaikh Muhammad Nawawi bin Umar, Qami'ut Tughyan ala Manzumat Shu'b al-Iman ..., 8.
} 
penduduk yang belajar kepadanya. Maka jika salah seorang telah melaksanakan hal ini, maka gugurlah kewajiban itu dari semuanya, tetapi jika tidak, maka berdosalah semuanya. Kelalaian orang alim adalah dalam tidak menyebarkan ilmunya, sedangkan kelalaian orang bodoh adalah tidak belajar". ${ }^{31}$

Pernyataan Syaikh Nawawi di atas memberikan pemahaman, bahwa menurutnya, semisal masjid atau wilayah tertentu, harus memiliki minimal seorang faqih (ahli fiqih). Faqih tersebut mengajarkan ilmunya kepada orang-orang. Faqih memberikan pemahaman kepada umat manusia tentang agama dan syariat Islam. Jadi keberadaan faqih atau alim di suatu wilayah merupakan keniscayaan untuk memenuhi kebutuhan umat dalam menjalankan ajaran agama dengan baik. Tanpa adanya seorang alim, faqih, maka umat manusia akan menghadapi kesulitan untuk melaksanakan kehidupan sesuai dengan syariat Islam. Masjid dan wilayah tertentu yang dimaksud adalah masjid dan atau wilayah di mana seorang faqih bertempat tinggal atau berdomisili.

Terdapat dua hal yang perlu diperhatikan oleh masyarakat dalam konteks ini, yaitu pertama masyarakat wajib memiliki minimal seorang faqih. Dalam memenuhi kewajiban ini, maka masyarakat seluruhnya harus berupaya untuk melahirkan faqih yang dimaksud, dengan cara mendidik generasinya hingga mencapai derajat alim dan faqih. Pendidikan yang diberikan harus dapat mengantarkan mereka pada kompetensi akademik agama Islam yang dibutuhkan. Pendidikan yang demikian dapat melalui jalur informal, nonformal, maupun formal. Dengan cara ini umat Islam memenuhi kewajibannya sendiri. Kedua masyarakat mendatangkan seorang faqih dari luar daerahnya, kemudian memintanya untuk berdomisili di daerah masyarakat tersebut. Cara ini dilakukan untuk memenuhi kebutuhan dan kewajiban yang tidak dapat dipenuhi sendiri oleh masyarakat yang bersangkutan. Dalam menempuh cara ini, seluruh anggota masyarakat di daerah tersebut haruslah bekerja sama dalam segala hal yang berkaitan dengan kehadiran faqih di daerah mereka.

Berikutnya, Syaikh Nawawi menjelaskan bahwa seorang alim atau faqih wajib kifayah menyebarkan ilmunya ke daerah lain (di luar tempat tinggalnya). Artinya, jika di daerah itu telah ada seorang yang melakukannya, maka kewajiban itu gugur bagi lainnya. Demikian pula, kewajiban ini dibebankan kepada faqih yang telah melaksanakan kewajiban individualnya. Jika seorang faqih tidak dapat menyebarkan ilmunya ke luar daerahnya karena terhalang oleh pelaksanaan kewajiban individualnya, maka faqih tersebut tidaklah berdosa. Sejalan dengan ini adalah pendapat KH. Hasyim Asy'ari yang mengatakan bahwa bukanlah suatu kebaikan pada umat jika generasinya (dibiarkan) bodoh, dan umat tidak akan menjadi baik kecuali dengan (menguasai) ilmu. ${ }^{32}$

Hal yang menarik dari pendapat Syaikh Nawawi, terkait dengan penyebaran ilmu oleh faqih di laur daerahnya. Dalam hal ini, Syaikh Nawawi mengharuskan faqih

31 Ibid., 8.

32 Muhammad Asad Sahab, al-'Allamah Muhammad Hashim Ash'ari (Beyrut: Dar al-Sadiq, 1971), 12. 
memiliki bekal sendiri untuk memenuhi kebutuhan pribadinya selama berada di tempat penyebaran ilmu. Menurut Syaikh Nawawi, faqih tidak diperkenankan makan makanan penduduk setempat. Jika dalam kondisi normal, artinya faqih yang sedang taklim di luar daerah memiliki bekal yang cukup untuk selama pelaksanaan, maka lebih baik faqih tidak meminta makanan dari penduduk setempat. Namun, jika situasinya sudah tidak normal, bekal yang dibawanya telah habis, sementara taklim bagi masyarakat di tempat itu harus terus dilaksanakan, maka tentunya masyarakat setempat harus memperhatikan kondisi ini. Yang sangat etis adalah, masyarakat segera mengusahakan dan memberikan segala kebutuhan pokok faqih, tidak menunggu sampai faqih meminta.

Dari pernyataan Syaikh Nawawi di atas juga dapat difahami bahwa seorang alim, ulama, faqih dianggap lalai menurut Allah Swt, jika tidak melaksanakan taklim hingga ke luar daeranya. Tentunya kelalaian ini akan berakibat dosa. Sedangkan orang awam dianggap lalai jika meninggalkan belajar, mengaji dan lain sebagainya dari segala bentuk upaya mencari ilmu. Sama juga, bahwa kelalaian ini berujung dosa. Dari ini, maka difahami, bahwa menurut Syaikh Nawawi, pihak yang harus

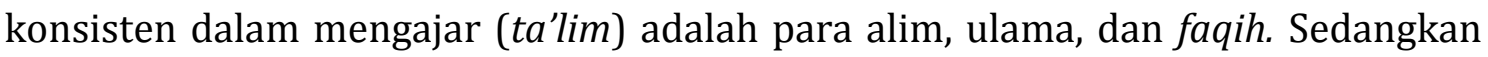
yang harus konsisten dalam belajar (ta'allum) adalah kaum awam. Dan jika konsistensi dua pihak ini terus dijaga maka mereka selamat dari perbuatan dosa, dan meraih pahala dari Allah Swt. Serta pula hakikat daripada pendidik tidak cukup sebagai sarana untuk mentransfer ilmu dari otak pendidik ke otak peserta didik, akan tetapi lebih mengedepankan kepada pembentukan akhlaq mulia serta suri tauladan yang baik dari pendidik. ${ }^{33}$

\section{Ulama Akhirat}

Kata ulama dalam sistem pendidikan Islam merujuk pada al-Qur'an dan alhadis. Antara lain pada surat Fatir ayat 28, yang artinya: “...Sesungguhnya yang takut kepada Allah di antara hamba-hamba-Nya, hanyalah ulama'. Sesungguhnya Allah Maha Perkasa lagi Maha Pengampun".34

Di dalam ayat tersebut kata ulama digunakan untuk menunjukkan identitas kaum yang takut kepada Allah. Kata Ulama' merupakan bentuk jamak dari 'alim, 'Alimuna bentuk jamak dari 'alim, keduanya memiliki arti sama yakni orang yang tahu. Yang dimaksud dengan ulama' dalam ayat ini ialah orang-orang yang mengetahui kebesaran dan kekuasaan Allah. ${ }^{35}$ Sedangkan menurut Ibn Luhai'ah dari Ibn Abi 'Amrah dari Ikrimah dari Ibn Abbar r.a. orang yang tahu terhadap Allah (al-'Ālim bi al-Rahmān) dari hamba-hamba-Nya adalah orang yang tidak menyekutukan Allah dengan sesuatu, menghalalkan apa yang yang dihalalkan oleh Allah, mengharamkan apa yang diharamkan oleh Allah, menjaga wasiat Allah dan

\footnotetext{
${ }^{33}$ Bashori, "Pemikiran Pendidikan Syekh Nawawi Al-Bantani”, HIKMAH: Jurnal Pendidikan Islam Vol. 6, No. 1 Januari - Juni 2017, 52.

${ }^{34}$ Departemen Agama R.I, Al-Qur'an Dan Terjemahnya ( Surabaya: Al-Hidayah, 1998), 700.

35 Ibid.
} 
berkeyakinan bahwa dirinya akan menghadap Allah serta yakin bahwa Allah akan menghisab amal perbutannya. ${ }^{36}$

Pokok pikiran lainnya, yang tertuang dalam kitab qami'ut tughyan, adalah mengenai ulama akhirat. Syaikh Nawawi menjelaskan beberapa prinsip yang menjadi ciri ulama akhirat. Dia mengatakan:

"Kemudian, ketahuilah bahwa ulama akhirat memiliki beberapa ciri, antara lain: pertama, ulama akhirat tidak mencari dunia dengan ilmunya. Kedua, di dalam menyibukkan diri dengan ilmu, ulama akhirat hanya bertujuan untuk kebahagiaan akhirat, sehingga dia lebih mementingkan ilmu bathin untuk mengatur hati. Dan ketiga, ulama akhirat berpegang pada ilmunya dengan mengikuti pemilik syariat dalam perkataan dan perbuatannya". ${ }^{37}$

Pernyataan di atas menunjukkan pemikiran Syaikh Nawawi tentang ulama akhirat. Menurutnya, ulama akhirat dapat dilihat dengan tiga ciri pokok, yaitu: (1) tidak mencari dunia dengan ilmunya; (2) mengharap kebahagiaan akhirat; dan (3) perkataan dan perbuatannya selalu sesuai dengan syariat. Ketiga ciri tersebut merupakan ciri pokok bagi ulama akhirat. Karena, lebih detail akan ditemukan lagi ciri yang lain, namun ciri detail tersebut merupakan turunan dari ciri pokok tersebut.

Menurut Syaikh Nawawi, seorang ulama akhirat tidak akan pernah menggunakan ilmunya atau kealimannya untuk meraih keuntungan duniawi. Ulama akhirat tidak akan pernah menukar ilmunya dengan harta, benda, maupun jabatan duniawi. Ulama akhirat akan menjauhkan dirinya dari kepentingan-kepentingan duniawi. Dia akan tetap komitmen para prinsip-prinsip ilmu yang dikuasainya, yakni bahwa ilmu bukan untuk mendulang harta benda, tetapi ilmu untuk kebahagiaan diri dan orang lain melalui amal shalih. Seorang ulama akhirat tidak akan menukar nilai keilmuannya dengan sebatas harta benda duniawi yang tidak berharga di mata Allah Swt. Ulama akhirat akan konsisten pada kaidah-kaidah keilmuan, meskipun harus menjadi miskin demi mempertahankan prinsip dan kaidah. Ulama akhirat tidak akan pernah terpengaruh oleh harta benda duniawi, sehingga tidak akan pernah mengubah prinsip dan substansi ilmunya. Al-Ghazali mengatakan bahwa ulama dibagai dalam dua kelompok, pertama ulama dunia, dan kedua adalah ulama akhirat. Ulama dunia adalah ulama' al-su' yakni mereka yang dengan ilmunya bertujuan untuk memperoleh kenikmatan dunia, mendapatkan kemulyaan dan kedudukan di mata manusia. ${ }^{38}$

Begitu pula tentang orientasi kebahagiaan. Ulama akhirat hanya memiliki orientasi kebahagiaan akhirat. Artinya, seorang ulama akhirat akan mementingkan dan mendahulukan segala sesuatu yang akan memberikannya kebahagiaan di akhirat. Ibadah yang dilakukan, ilmu yang disebarkan, bahkan segala seuatunya hanya diproyeksikan untuk memperoleh kebahagiaan akhirat belaka. Sedangkan

\footnotetext{
${ }^{36}$ al-Imam Abu al-Fada' al Hafid Ibn Kathir al-Damashqy, Tafsīr al-Qur'ān al-'Azịm al-Juz' 3 (Beyrut Libanon: Dar al-Fikr, 2005), 1542.

${ }^{37}$ Syaikh Muhammad Nawawi bin Umar, Qami'ut Tughyan ala Manzumat Shu'b al-Iman ..., 8.

${ }^{38} \mathrm{Al}$-Ghazali, Ihya' Ulum al-Din Juz I (Beirut: dar al-kutub al-Imliyah, 2012), 82.
} 
tentang kecocokan antara apa yang dikatakan dengan apa yang dilakukan merupakan ciri yang kental terlihat pada seorang ulama akhirat. Menurut Syaikh Nawawi, ulama akhirat akan melakukan yang ia katakan, dan akan mengatakan yang ia lakukan. Tidak akan ditemukan kontradiksi antara apa yang dikatakan dengan apa yang dilakukan. Jika dia mengatakan suatu perbuatan adalah wajib, atau sunnah, maka pasti dia akan melakukannya, sedangkan jika suatu perbuatan dikatakan haram atau makruh, maka dia akan meninggalkannya. Demikianlah kesesuaian antara ucapan dan perbuatan seorang ulama akhirat.

Terkait dengan ciri ulama akhirat tidak mencari harda benda duniawi dengan ilmunya, Syaikh Nawawi menunjukkan beberapa ciri dengan mengatakan:

"kemudian, sesungguhnya ada lima ciri bagi (ulama akhirat) yang tidak mencari harta benda duniawi dengan ilmu, yaitu; (1) tidak ada kontradiksi antara apa yang dikatakan dengan yang dilakukan, maka jadilah dia orang pertama yang melakukan yang diperintahkan, dan orang pertama yang menjauhi yang dilarang; (2) bersungguh-sungguh dengan ilmunya menurut kemampuannya, mendekatkan pada ketaatan, dan menjaga diri dari kuantitas ilmu untuk berdebat; (3) menjauhkan diri dari kemewahan makanan, tempat tinggal, maupun pakaian; (4) menjauhi pejabat atau penguasa kecuali untuk memberikan nasihat kepadanya atau untuk mencegah kedhaliman, atau menolong di dalam keridlaan Allah Swt; dan (5) tidak segera mengeluarkan fatwa, bahkan karena berhati-hati, dia mengatakan: mintalah (fatwa) kepada ahlinya. Dan menolak untuk ijtihad tertentu manakala materi ijtihadnya belum jelas baginya. Bahkan, dia mengatakan: saya tidak tahu, jika ijtihad memang tidaklah mudah baginya". 39

Setelah Syaikh Nawawi pada pernyataan sebelumnya menegaskan bahwa salah satu ciri ulama akhirat adalah tidak mencari harta benda duniawi dengan ilmunya, maka berikutnya Syaikh Nawawi merinci beberapa ciri ulama yang tidak mencari harta benda duniawi dengan ilmunya. Menurutnya, terdapat lima ciri ulama yang tidak mencari harta benda duniawi dengan ilmunya antara lain:

Pertama, ulama akhirat yang benar-benar tidak mencari harta benda duniawi dengan ilmunya tidak menunjukkan ketidakcocokan atau kontradiksi antara apa yang dikatakan dengan yang dilakukannya. Sesuatu yang menurut hukum wajib dilakukan, maka dia akan mengatakan wajib pula, dan dia akan melaksanakan kewajiban itu dengan baik. Ulama akhirat konsisten terhadap hukum dan ketentuan syariat. Segala sesuatu yang menurut syariat haram dan harus dijauhi, maka dia akan mengatakan hal itu kepada siapapun bahwa hal itu haram, kemudian dia akan menjauhinya sejauh-jauhnya sebelum orang lain menjauhinya. Ulama yang dimaksud di sini tidak akan terlihat bertolak belakang antara ucapan dan perbuatan. Karena jika ucapannya wajib, maka perbuatannya adalah melakukan kewajiban itu, tetapi jika ucapanya adalah haram, maka perbuatannya adalah menjauhi yang

\footnotetext{
${ }^{39}$ Syaikh Muhammad Nawawi bin Umar, Qami'ut Tughyan ala Manzumat Shu'b al-Iman ..., 8.
} 
haram tersebut. Ucapan dan perbuatan ulama ini sesuai dengan syariat: al-Quran dan hadis.

Kedua bersungguh-sungguh dengan ilmunya menurut kemampuannya, mendekatkan pada ketaatan, dan menjaga diri dari kuantitas ilmu untuk berdebat; ilmu yang dimiliki tidak dipergunakan untuk berdebat, untuk mengalahkan orang lain, untuk membuat orang lain malu. Ketiga menjauhkan diri dari kemewahan makanan, tempat tinggal, maupun pakaian; ini merupakan karakter ulama akhirat yang hingga saat ini dapat kita jumpai secara langsung pada pribadi ulama akhirat. Kemewahan makanan, pakaian, tempat tinggal maupun lainnya tidak lah penting, yang penting bagi para ulama akhirat adalah kemanfaatannya untuk semata-mata mengabdi kepada Allah Swt.

Keempat menjauhi pejabat atau penguasa kecuali untuk memberikan nasihat kepadanya atau untuk mencegah kedhaliman, atau menolong di dalam keridlaan Allah Swt; ulama akhirat bukanlah anti atau pembenci penguasa, pun juga tidaklah ulama akhirat mengekor kepada penguasa. Ulama akhirat memposisikan dirinya sebagai penegak keadilan dan kebenaran bagi para penguasa. Dalam kepentingan membela kebenaran dan keadilan, ulama akhirat akan mendatangi penguasa untuk memberikan nasihat dan menyampaikan kebenaran demi tegaknya keadilan di tengah-tengah masyarakat. Kelima tidak segera mengeluarkan fatwa bahkan karena berhati-hati, dia mengatakan: mintalah (fatwa) kepada ahlinya. Dan menolak untuk melakukan ijtihad tertentu manakala materi ijtihadnya belum jelas baginya. Bahkan, dia mengatakan: saya tidak tahu, jika ijtihad memang tidaklah mudah baginya. Merendah, itulah prinsip ulama akhirat. Jika masih ada orang lain yang lebih ahli, maka ulama akhirat akan mempersilakan kepadanya untuk menentukan fatwa atau ijtihad tertentu. Jadi, ulama akhirat bukanlah orang yang sombong, dan bukanlah orang yang hanya menginginkan pujian dari sana sini.

\section{Relevansi Pemikiran Syaikh Nawawi dalam Pembentukan Karakter Pendidik}

Melihat relevansi pemikiran Syaikh Nawawi pada kitab qami'ut tughyan ini dengan pelaksanaan pendidikan masa kini, maka kita akan temukan sesuatu yang sederhana tetapi kompleks. Sederhana di sini maksudnya adalah pemikiran Syaikh Nawawi mengenai karakter pendidik sangatlah mudah dipahami dan sangat mendasar sekali, antara lain: pendidik haruslah mengutamakan keilmuanya, bukan keuntungan duniawi dari ilmunya, sehingga para pendidik akan tetap konsisten dalam melaksanakan kewajiban transformasi ilmu kepada generasi berikutnya, bukan untuk mencari keuntungan duniawi. Pun juga mengenai pendidik diharapkan menjauhi kemewahan dunia. Hal ini akan membentuk karakter pendidik yang ikhlas karena Allah Swt dalam menyebarkan ilmunya. Dalam penguasaan bidang ilmu, pendidik dituntut untuk tidak menyombongkan diri kepada siapapun. Karena ilmu yang dikuasai bukanlah untuk disombongkan melainkan untuk diamalkan dan disebarkan kepada umat. Dalam hal ini, karakter pendidik yang terbentuk adalah rendah hati tetapi konsisten dalam berucap, dan bertindak pada ilmunya. Karakter 
yang penting juga adalah gigih dalam mendidik, tidak mengenal putus asa, karena bagi pendidik bukanlah keberhasilan peserta didik dalam menguasai ilmu tertentu yang dituntut, melainkan keistiqamahan pendidik dalam mendidiklah yang dihitung sebagai kesuksesan.

\section{Kesimpulan}

Dari uraian di atas, dapat disimpulkan bahwa: Pemikiran Syaikh Nawawi dalam kitab qami'ut tughyan meliputi pembahasan tentang ilmu dan ulama. Pemikiran Syaikh Nawawi tentang ilmu dan ulama dalam kitab qami'ut tughyan meliputi: (a) pembahasan tentang landasan nas hadis tentang ilmu yang dapat memotivasi umat Islam untuk mencari ilmu sedemikian rupa; (b) pembahasan tentang niat pencari ilmu yang dibenarkan menurut syariat; (c) pembahasan tentang kewajiban menyebarkan ilmu terletak pada setiap orang yang menguasai suatu bidang ilmu; dan (d) pembahasan tentang prinsip dan ciri ulama akhirat. Pemikiran Syaikh Nawawi tentang ilmu dan ulama dalam kitab qami'ut tughyan memberikan pemahaman bahwa pendidik mestinya memiliki karakter yang kuat sebagai ahl al-ilmi yang komitmen terhadap ilmunya, konsisten dalam mendidik, dan mengutamakan tujuan akhirat.

\section{Daftar Pustaka}

Azra, Azyumardi, Jaringan Ulama Timur Tengah dan Kepulauan Nusantara Abad XVII-XVIII: Akar Pembaruan Islam Indonesia. Jakarta: Kencana Prenada Media Group, 2013.

Bahary, Anshar, "Tafsir Nusantara, Studi Kritis Terhadap Marāḥ Labīd Nawawi alBantani", Jurnal Ulul Albab, Volume 16 No. 2 tahun 2015.

Bashori, "Pemikiran Pendidikan Syekh Nawawi Al-Bantani", HIKMAH: Jurnal Pendidikan Islam Vol. 6, No. 1 Januari - Juni 2017.

Bukhari, Abi Abdillah Muhammad bin Ismail al-, Matn al-Bukhari Juz I. Sanggapura, Indonesia: Al-Haramayn, tt.

Departemen Agama R.I, Al-Qur'an Dan Terjemahnya. Surabaya: Al-Hidayah, 1998.

Fahmi, Muhammad Ulul, Ulama Besar Indonesia Biografi dan Karyanya. Kendal: Amanah Grafika, 2008.

Ghazali, Al-, Ihya' Ulum al-Din Juz I. Beirut: dar al-kutub al-Imliyah, 2012.

Ghazali, Al-, al-Risalah al-Ladduniyah. Mesir: Kurdistan al-Ilmiyah, 1328.

Hidayatullah, M. Ridwan dan Aceng Kosasih Fahrudin, "Konsep Tasawuf Syaikh Nawawi al-Bantani", Jurnal Tarbawi, Vol 2 tahun 2015.

Ibn Kathir, al-Imam Abu al-Fada' al Hafid, Tafsīr al-Qur'ān al-'Azim al-Juz' 3. Beyrut Libanon: Dar al-Fikr, 2005.

Khusaeri, "Pemikiran Syekh Nawawi al-Bantani Dalam Bidang Hukum Islam (Tentang Taklif dan Mukalaf)", Al-A'raf: Jurnal Pemikiran Islam dan Filsafat, Vol. XI, No. 1, Januari-Juni 2014.

Maftuh, Rofik, "Inklusisifitas Pemikiran Syaikh Nawawi al-Bantani; Studi Atas Konsep Ahl al-Fatrah dalam Tafsir Marāḥ Labīd", MAGHZA: Jurnal Ilmu AlQur'an dan Tafsir, Vol. 3, No. 1, Januari-Juni 2018. 
Muqoddas, Ali, "Syeikh Nawawi Al-Bantani al-Jawi: Ilmuan Spesialis Ahli Syarah Kitab Kuning". Jurnal Tarbawi. Vol. 11. No. 1. Januari-Juni 2014.

Nawawi, Syaikh Muhammad, Qami'ut Tughyan ala Manzumat Shu'b al-Iman. Sanggapura, Indonesia: al-Haramyn, tt.

Shahab, Muhammad Asad, al-'Allamah Muhammad Hashim Ash'ari. Beyrut: Dar alSadiq, 1971. 